\title{
A Scale to Measure the Role Perception of Women Members of Gram Panchayat
}

\author{
V. K. Chaithra* and Annapurna Kalal
}

Department of Extension and Communication Management, College of Community Science

University of Agricultural Sciences, Dharwad, Karnataka, India

*Corresponding author

\section{A B S T R A C T}

\begin{tabular}{|l|}
\hline Ke y w o r d s \\
Role, Perception, \\
$\begin{array}{l}\text { Gram Panchayat, } \\
\text { Women, Members }\end{array}$ \\
\hline Article Info \\
\hline $\begin{array}{l}\text { Accepted: } \\
\text { 12 December } 2020 \\
\text { Available Online: } \\
\text { 10 January } 2021\end{array}$ \\
\hline
\end{tabular}

\section{Introduction}

The Panchayats are among the oldest institutions for local governance in India. It ensures the participation of local people in the development programmes including women representing the cross section of the society at village, taluk and at district level also called as the three tier system of decentralized administration. Gram Panchayat is the 
primary body of the rural local selfgovernment, working as an executive committee of the Gram Sabha. In the three tier system of democratic decentralization of Panchayat Raj, the Gram Panchayat functions at the grass root level i.e. at the village level. Gram Panchayats are democratically elected local governments and have crucial role in shaping local socio-economic development and addressing the diverse social needs of the rural community.

Greater involvement of women in socioeconomic and political affairs is becoming crucial for their own development. Women constitute nearly half of the country's population. For healthy political system and welfare of the people, it is necessary that women must come forward and play an active role in country's political affairs. Women are playing important role in governance of India through Panchyat Raj Institutions (PRIs). Their increased political participation has yielded positive result in development issues such as education, health, nutrition and increase in family income during last quarter of the century.

The elected women members of Gram Panchayat are supposed to play very important role for the overall development and specially for women and children welfare. The role performance of the elected women members is greatly dependent on how they perceive and execute their role. The success of any Gram Panchayat largely depends upon how well the elected members perceive their roles within the framework of Panchayat Raj constitution. Hence, it is necessary for the women members of Gram Panchayat to have an understanding of their roles and its effective implementation for the development of village. Hence, the research was taken up with an objective to develop and standardize a scale to measure the role perception of women members of Gram Panchayat.

\section{Materials and Methods}

The present study was conducted during 2019- 2020. The method suggested by the Likert (1932) in developing summated rating scale was used to construct the role perception scale. The details of the steps followed and standardization of the scale to measure the role perception of women members of Gram Panchayat is explained as below.

\section{Selection of items}

The behavioral characteristics associated with role perception formed the base material for the items. Based on the relevant research studies, wide range of discussion with Extension Professionals, Panchayat Development Officers, resource persons of Panchayat, Gram Panchayat members and by reviewing the job chart of Gram Panchayat women members, the items needed for measuring role perception of Gram Panchayat women members were formulated under the abovementioned five broad areas. These were edited using the criteria suggested by Likert (1932)to make them free from double negative, ambiguity and complexity. After editing 49itemswere retained under five different broad areas.

\section{Relevancy weightage}

Each of the five identified components consisted of items ranging from 1 to 15 in number. They were subjected to an expert panel of judges to determine the relevancy and their subsequent screening. For this purpose, the items were sent to 150 experts/scientists from different State Agricultural Universities (SAU's), resource persons of Panchayat and Panchayat Development Officers. The judges were requested to indicate their response as "most relevant", "relevant" and "not relevant" for appropriateness of each item for inclusion in 
the scale to measure a particular component of role perception. A total of 75 responses were received from the judges. The judgments were used to work out the relevancy weightage (RW) of each item as given below

Most relevant $\times 2+$ Relevant $\times 1+$ Not relevant $\times 0$

Relevancy weightage $(\mathrm{RW})=\frac{\text { Most relevant } \times 2+\text { Relevant } \times 1+\text { Not relevant } \times 0}{\text { Maximum possible score }}$

The items having relevancy weightage of more than or equivalent to 0.75 were selected (Table1). Finally, 33 items were retained from 4 components i.e. 10 under Administrative roles, 7under Agriculture and allied roles, 8Women and Child Welfare roles and 8 under Social Welfare roles.

\section{Item analysis}

Item analysis was carried out in order to know the women members of Gram Panchayat degree of favorableness towards each statement included in the role perception of women members of Gram Panchayat. For this purpose, 33 items qualified in the relevancy test were selected.

A schedule consisting of 33 statements was prepared and it was used to interview 30 women members of Gram Panchayat from a non-sample area. The respondents were asked to indicate their degree of agreement or disagreement with each statement on a five point continuum viz., strongly agree, agree, undecided, disagree and strongly disagree with scores of 4, 3, 2, 1 and 0 respectively.

The respondent's responses were recorded and the summated score for the total statements of each respondent is obtained. The scores of the respondents were then arranged in a descending order. Twenty five per cent (25.00 per cent) from highest scores (high group) and 25 per cent from lowest scores (low group) were taken for the item analysis. These two groups formed the criterion groups for item analysis. The critical ratio $(\mathrm{t})$ for each item was calculated by using following formula.

$$
t=\frac{\bar{X}_{\mathrm{H}}-\bar{X}_{\mathrm{L}}}{\frac{\sqrt{\left(\sum \bar{X}_{\mathrm{H}}^{2}-\frac{\left(\sum \overline{X_{\mathrm{H}}}\right) \rrbracket^{2}}{n}\right) \times\left(\sum \bar{X}_{\mathrm{L}}^{2}-\frac{\left.\left(\sum \overline{X_{\mathrm{L}}}\right)\right]^{2}}{n}\right)}}{n(n-1)}}
$$

Where,

$\bar{X}_{\mathrm{H}}=$ The mean score on given statement of the high group

$\bar{X}_{\mathrm{L}}=$ The mean score on given statement of the low group

$\sum X^{2}{ }_{H}=$ Sum of squares of the individual score on a given statement for high group

$\sum \mathrm{X}_{\mathrm{L}}^{2}=$ Sum of squares of the individual score on a given statement for low group

$\mathrm{n}=$ Number of respondents in each group

$\mathrm{t}=$ The extent to which a given statement differentiate between the high and low group.

The ' $t$ ' value is the measure of extent to which given statement differentiates between high and low groups. The items with ' $\mathrm{t}$ ' value equal to or greater than 2.18 (at 5.00 per cent level of probability) were selected as final statements (Table 2). The thumb rule of rejecting items with ' $\mathrm{t}$ ' value less than 2.18 was followed by Edwards A L. (1957). As per the thumb rule, selection of items to be retained in the scale includes the scales with highest discriminating values, excluding the scales with poor discriminating ability and questionable validity. Finally 28 statements/items were retained in the scale. 
These 28 items/statements formed the "Role Perception scale" and was used to measure the role perception of women members of Gram Panchayat (Table 3).

\section{Testing Validity of the scale}

Guliford (1954) reported that, a test is valid when it measures what it is supposed to measure. Validity of the scale to measure the role perception of women members of Gram Panchayat was ensured by establishing "content validity" and "construct validity".

\section{Content validity}

In the present study, the components and sub components of role perception were identified through review of relevant literature and discussion with experts in the concerned field. The judge's opinion was sought to know the relevancy of the main and sub-components. This justified the content validity of the scale.

\section{Construct validity}

The construct validity of an instrument is the extent to which one can be sure it represents the construct whose name appears in its title (Henerson et al., 1978). In order for the operating measure to have construct validity, the operating measure must demonstrate that it measures the specific construct and not other constructs. The validity of the scale was measured by following method.

\section{Correlation of the sub-component scores with total scores}

A construct is valid in many occasions by the method of internal consistency (Anastasi, 1976). The essential characteristic of this method is that the criterion is none other than the total score of the test itself. The method involves finding the correlation of subcomponent scores with total scores of the test.
The scale developed for the study was administered to 30 Gram Panchayat women members other than the respondents selected for the study to measure the role perception of women members of Gram Panchayat. The correlation coefficients between scores obtained by each of the components of the role perception and total score were 0.801 , $0.772,0.875$ and 0.877 respectively. The high values of correlation coefficient justified construct validity of the scale.

\section{Testing reliability of the Scale}

According to Kerlinger (1973) reliability is the accuracy or precision of the measuring instrument. A scale is said to be reliable when it consistently produces the same results when applied to measure the same phenomena from time to time.

According to Anastasi (1976) reliability refers to the consistency of scores obtained by the same individual when examined with test on different occasions or with different sets of equivalent items, or under other variable examining conditions.

Any newly constructed scale has to be tested for its reliability. In the present study, the reliability of scale was determined by using split - half reliability technique.

\section{Split-half reliability}

In this method, the scale was split in to two equal halves on the basis of odd and even number of statements and administered to 30 women members of Gram Panchayat from non-sample area. The correlation co-efficient was computed between the two sets of scores of the scale. The reliability co-efficient of the statements of four components of role perception of women members of Gram Panchayat was 0.80 , which was found significant at 0.01 level of probability. 
Administration and scoring of perception scale

The final scale consisted 28 statements. The responses were recorded on a five point continuum representing strongly agree, agree, undecided, disagree and strongly disagree with scores of 4, 3, 2, 1 and 0 respectively. The scores of all the items were summated to get the role perception score of Gram Panchayat women members.

The scores ranged from a minimum of ' 0 ' to maximum of ' 112 '. Higher the perception score indicates the good role perception and lesser perception score indicates poor role perception by women members of Gram Panchayat.
Total score for each respondent was calculated and classified into three categories using class interval with the help of below mentioned formula.

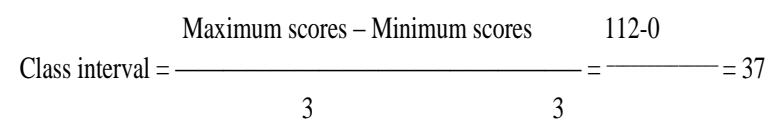

Based on the scores obtained by each individual the respondents were classified as low, medium and high level of role perception as given below

\begin{tabular}{|c|c|}
\hline Category & Range \\
\hline Poor & $0-37$ \\
\hline Medium & $38-74$ \\
\hline Good & $75-112$ \\
\hline
\end{tabular}

Table.1 Statement / item wise relevancy weightage of role perception of women members of Gram Panchayat

\begin{tabular}{|c|l|c|}
\hline SI. No & \multicolumn{1}{|c|}{ Statements } & $\begin{array}{c}\text { Relevancy } \\
\text { weightage }\end{array}$ \\
\hline A. & Administrative roles & 0.75 \\
\hline $\mathbf{1}$ & Multiple roles to be played in administration & 0.81 \\
\hline $\mathbf{2}$ & Encourage and involve local people in decision making & 0.82 \\
\hline $\mathbf{3}$ & Monitoring the performance of the Gram Panchayat to achieve the set targets & 0.86 \\
\hline $\mathbf{4}$ & Guiding local people in getting the benefits of government schemes & 0.57 \\
\hline $\mathbf{5}$ & Motivating and collecting village related taxes & 0.81 \\
\hline $\mathbf{6}$ & $\begin{array}{l}\text { Participation in decision making of Panchayat for all round development of the } \\
\text { village/s }\end{array}$ & 0.88 \\
\hline $\mathbf{7}$ & Active participation while preparing budget for the village development \\
\hline $\mathbf{8}$ & Monitoring the prompt registration and reporting of births and deaths & 0.55 \\
\hline $\mathbf{9}$ & Maintenance of records relating to all activities of Gram Sabha & 0.79 \\
\hline $\mathbf{1 0}$ & Fairly, impartial and quick response to enquiries of the people & 0.81 \\
\hline $\mathbf{1 1}$ & Participation in all the meetings of Gram Panchayat & 0.83 \\
\hline $\mathbf{1 2}$ & $\begin{array}{l}\text { Representation of the dignity and interest of people of all religions and different } \\
\text { socio-economic categories }\end{array}$ & 0.67 \\
\hline $\mathbf{1 3}$ & Making use of e-panchayat helps for better administration & 0.76 \\
\hline $\mathbf{B .}$ & Agriculture and allied roles & 0.79 \\
\hline $\mathbf{1}$ & $\begin{array}{l}\text { Confirmation of the fair distribution of inputs such as seeds, fertilizers, subsidies } \\
\text { etc, to all the farmers }\end{array}$ & 0.75 \\
\hline $\mathbf{2}$ & Help the developmental departments in performing their functions at village/s & \\
\hline & & \\
\hline
\end{tabular}




\begin{tabular}{|c|c|c|}
\hline 3 & Manage natural calamities with proper mitigation activities & 0.67 \\
\hline 4 & $\begin{array}{l}\text { Help villagers in getting loan for agriculture and allied activities such as dairy, } \\
\text { poultry etc, }\end{array}$ & 0.80 \\
\hline 5 & Motivation of villagers to repay crop loans & 0.77 \\
\hline 6 & Get irrigation sources constructed and their maintenance & 0.75 \\
\hline 7 & Provide proper storage facilities to the agricultural producers in the village/s & 0.75 \\
\hline 8 & Guide farmers in getting good price for their produces in markets & 0.77 \\
\hline 9 & Proper infrastructure such as construction of small roads to reach the fields & 0.69 \\
\hline C. & Women and Child Welfare roles & \\
\hline 1 & Awareness creation about laws for protection of women and others & 0.81 \\
\hline 2 & Preventing violence against women in the village/s & 0.87 \\
\hline 3 & Making arrangements for organizing health and vaccination campaigns & 0.85 \\
\hline 4 & Providing formal and non-formal education to women and children & 0.79 \\
\hline 5 & $\begin{array}{l}\text { Creating awareness about the consequences of child marriages, child labour and } \\
\text { other gender issues }\end{array}$ & 0.84 \\
\hline 6 & Preventing child marriages/child labour & 0.85 \\
\hline 7 & Increasing enrolment of girl students in schools & 0.85 \\
\hline 8 & Participation in implementation of women and child welfare activities & 0.85 \\
\hline 9 & Implementation of family planning projects & 0.67 \\
\hline D. & Social welfare roles & \\
\hline 1 & Monitoring the quality education and food supplied to the children in the schools & 0.79 \\
\hline 2 & $\begin{array}{l}\text { Implementation of health and nutrition programmes for the welfare of the school } \\
\text { children and villagers }\end{array}$ & 0.82 \\
\hline 3 & Ensuring full enrollment of children in primary and high school & 0.67 \\
\hline 4 & $\begin{array}{l}\text { Assisting the implementation of the pension/financial assistance/rehabilitation } \\
\text { schemes for old age, divorcees and handicapped }\end{array}$ & 0.69 \\
\hline 5 & $\begin{array}{l}\text { Creating awareness about various government welfare schemes and arrange for } \\
\text { implementation of the same }\end{array}$ & 0.75 \\
\hline 6 & Creating facilities for safe drinking water for better public health and hygiene & 0.87 \\
\hline 7 & $\begin{array}{l}\text { Generating employment opportunities through MGNREGA and such other } \\
\text { employment programmes for the needy }\end{array}$ & 0.82 \\
\hline 8 & $\begin{array}{l}\text { Organizing skill development programmes through exhibitions, seminars, training } \\
\text { programmesetc }\end{array}$ & 0.78 \\
\hline 9 & Motivating the rural artisans under Khadi Gramodyoga & 0.66 \\
\hline 10 & Creating infrastructure facilities like roads, bus stand, electricity etc. & 0.78 \\
\hline 11 & Ensuring proper sanitation and drainage facilities in the village/s & 0.87 \\
\hline 12 & Motivating and implementing projects on renewable energy sources & 0.67 \\
\hline 13 & Organizing and motivating adult education and non-formal education & 0.68 \\
\hline 14 & Establishment of village library & 0.59 \\
\hline 15 & Organizing and monitoring of village festivals including animal fairs & 0.54 \\
\hline
\end{tabular}


Table.2 Item discrimination index (' $t$ ') of role perception of women members of Gram Panchayat

\begin{tabular}{|c|c|}
\hline Items & Item Discrimination Index (' $t$ ' value) \\
\hline 1 & 0.3515 \\
\hline 2 & 3.3466 \\
\hline 3 & 2.9580 \\
\hline 4 & 2.4495 \\
\hline 5 & 2.2687 \\
\hline 6 & 2.6732 \\
\hline 7 & 1.7321 \\
\hline 8 & 2.2913 \\
\hline 9 & 2.6054 \\
\hline 10 & 0.2594 \\
\hline 11 & 2.6732 \\
\hline 12 & 2.4495 \\
\hline 13 & 2.2687 \\
\hline 14 & 2.4495 \\
\hline 15 & 2.7386 \\
\hline 16 & 2.7495 \\
\hline 17 & 5.4006 \\
\hline 18 & 3.00 \\
\hline 19 & 2.9580 \\
\hline 20 & 2.2687 \\
\hline 21 & 1.7396 \\
\hline 22 & 2.9580 \\
\hline 23 & 5.4006 \\
\hline 24 & 3.3466 \\
\hline 25 & 2.2687 \\
\hline 26 & 2.9580 \\
\hline 27 & 2.4495 \\
\hline 28 & 2.2687 \\
\hline 29 & 2.2912 \\
\hline 30 & 2.2913 \\
\hline 31 & 1.7168 \\
\hline 32 & 2.2913 \\
\hline 33 & 5.4006 \\
\hline
\end{tabular}


Table.3 A scale to measure the role perception of women members of Gram Panchayat

\begin{tabular}{|c|c|c|c|c|c|c|}
\hline \multirow[t]{2}{*}{ Sl. No } & \multirow[t]{2}{*}{ Statements } & \multicolumn{5}{|c|}{ Role perception } \\
\hline & & SA & $\mathbf{A}$ & UD & DA & SDA \\
\hline A. & Administrative roles & & & & & \\
\hline 1 & Encourage and involve local people in decision making & & & & & \\
\hline 2 & $\begin{array}{l}\text { Monitoring the performance of the Gram Panchayat activities to achieve } \\
\text { the set targets }\end{array}$ & & & & & \\
\hline 3 & Guiding local people in getting the benefits of government schemes & & & & & \\
\hline 4 & $\begin{array}{l}\text { Participation in decision making of Panchayat for all round development } \\
\text { of the village/s }\end{array}$ & & & & & \\
\hline 5 & Active participation while preparing budget for the village development & & & & & \\
\hline 6 & Fairly, impartial and quick response to enquiries of the people & & & & & \\
\hline 7 & Participation in all the meetings of Gram Panchayat & & & & & \\
\hline B. & Agriculture and allied roles & & & & & \\
\hline 1 & $\begin{array}{l}\text { Confirmation of the fair distribution of inputs such as seeds, fertilizers, } \\
\text { subsidies etc, to all the farmers }\end{array}$ & & & & & \\
\hline 2 & $\begin{array}{l}\text { Help the developmental departments in performing their functions at } \\
\text { village/s }\end{array}$ & & & & & \\
\hline 3 & $\begin{array}{l}\text { Help villagers in getting loan for agriculture and allied activities such as } \\
\text { dairy, poultry etc, }\end{array}$ & & & & & \\
\hline 4 & Motivation of villagers to repay crop loans & & & & & \\
\hline 5 & Get irrigation sources constructed and their maintenance & & & & & \\
\hline 6 & $\begin{array}{l}\text { Provide proper storage facilities to the agricultural producers in the } \\
\text { village/s }\end{array}$ & & & & & \\
\hline 7 & Guide farmers in getting good price for their produces in markets & & & & & \\
\hline C. & Women and Child Welfare roles & & & & & \\
\hline 1 & Preventing violence against women in the village/s & & & & & \\
\hline 2 & Awareness creation about the laws for protection of women & & & & & \\
\hline 3 & Making arrangements for organizing health and vaccination campaigns & & & & & \\
\hline 4 & $\begin{array}{l}\text { Creating awareness about the consequences of child marriages, child } \\
\text { labour and other gender issues }\end{array}$ & & & & & \\
\hline 5 & Preventing child marriages/child labour & & & & & \\
\hline 6 & Increasing enrolment of children in schools & & & & & \\
\hline 7 & Participation in implementation of women and child welfare activities & & & & & \\
\hline D. & Social welfare roles & & & & & \\
\hline 1 & $\begin{array}{l}\text { Monitoring the quality education and food supplied to the children in the } \\
\text { schools }\end{array}$ & & & & & \\
\hline 2 & $\begin{array}{l}\text { Implementation of health and nutrition programmes for the welfare of } \\
\text { the school children and villagers }\end{array}$ & & & & & \\
\hline 3 & $\begin{array}{l}\text { Creating awareness about various government welfare schemes and } \\
\text { arrange for implementation of the same }\end{array}$ & & & & & \\
\hline 4 & $\begin{array}{l}\text { Creating facilities for safe drinking water for better public health and } \\
\text { hygiene }\end{array}$ & & & & & \\
\hline 5 & $\begin{array}{l}\text { Generating employment opportunities through MGNREGA and such } \\
\text { other employment programmes for the needy }\end{array}$ & & & & & \\
\hline 6 & Creating infrastructure facilities like roads, bus stand, electricity etc. & & & & & \\
\hline 7 & Ensuring proper sanitation and drainage facilities in the village/s & & & & & \\
\hline
\end{tabular}

Strongly agree (SA), Agree (A), Undecided (UD), Disagree (DA) and Strongly Disagree (SDA) 
In conclusion the scale developed to measure the role perception of women members of Gram Panchayat was found to be reliable and valid. The role perception scale developed was administered to 30 women members of Gram Panchayat of non - sample area. During the data collection, there were no complications in using the scale. Hence it can be concluded that the scale developed was useful in explicitly measuring the role perception of women members of Gram Panchayat. The scale developed can be used to measure the role perception and role performance of women members of Gram Panchayat in other parts of the country.

\section{References}

Likert, R., 1932, A technique for the measurement of attitudes. Arch. Psych., $140: 153$.
Edwards, A. L., 1957, Techniques of attitude scale construction. Appleton-century crofts, New York. English, H.B. and English, A.C., 1958, A Comparative dictionary of psycho analytical terms. Green and Co. Longemans, New York.

Guilford, J. P., 1954, Psychometric Methods, Tata McGraw Hill Publishing Co., Bombay, pp. 378-382.

Henerson, M. E., Morris, L. L. and Fitz Gibson., C. T., 1978, How to Measure Attitudes. Sage publications. London, p. 136.

Anastasi, A., 1976, Psychological Testing, The Macmillan Company., New York, p. 29.

Kerlinger, F. N., 1973, Foundation of Behavioural Research. Holt Rinc Hart Winston International, New York, p. 379.

\section{How to cite this article:}

Chaithra, V. K. and Annapurna Kalal. 2021. A Scale to Measure the Role Perception of Women Members of Gram Panchayat. Int.J.Curr.Microbiol.App.Sci. 10(01): 1463-1471. doi: https://doi.org/10.20546/ijcmas.2021.1001.174 